\begin{tabular}{c|c|c|}
\hline \hline & International Journal of Current Research in \\
\hline & Biosciences and Plant Biology \\
\hline EXCELLENT \\
PUBLISHERS
\end{tabular}

\title{
Contribution to traditional knowledge used for the prevention and healing of the Covid-19 symptoms by local people of Deng-Deng massif forest Cameroon
}

\author{
Inimbock Sorel Léocadie ${ }^{1}{ }^{1}$, Chimi Djomo Cédric ${ }^{1,2}$, Enamba Yaya Christian ${ }^{1}$, Tsemo \\ Tchuenwo Diane Christelle ${ }^{1}$, Somnjom Edwin Dinayen ${ }^{1}$, Mounmenie Kpoumie Hubert $\mathbb{D}^{3}$, \\ Bogne Tatcheu Line Véronique $\mathbb{( i}^{3}$, Noudem Jolie Claire $\mathbb{D}^{2}$, Nanfack Tchatchouang \\ Chanceline Laure ${ }^{3}$, Misse Alain Christian (id 1
}

\author{
${ }^{1}$ Institute of Agricultural Research for the Development (IRAD), B.P. 203, Bertoua, Cameroon \\ ${ }^{2}$ Conservation and Sustainable Natural Resources Management Network (CSNRM-Net), Yaounde-Cameroon \\ ${ }^{3}$ National Herbarium of Cameroon (NHC), B.P. 1601, Yaounde, Cameroon
}

*Corresponding author; e-mail: sorelinimbock@yahoo.fr

\begin{tabular}{|c|c|}
\hline Article Info & Abstract \\
\hline $\begin{array}{l}\text { Keywords: } \\
\text { Deng-Deng massif } \\
\quad \text { forest } \\
\text { Medicinal plants } \\
\text { Pandemic } \\
\text { Traditional medicine } \\
\text { Viral disease }\end{array}$ & $\begin{array}{l}\text { SARS-CoV-2 which causes the corona virus disease } 2019 \text { (Covid-19) continues to spread worldwide, } \\
\text { causing death and panic in rural communities with little emergency medical facilities. The efficiency } \\
\text { of traditional medicine has become the priority to prevent this pandemic. The aim of this study was to } \\
\text { identify local knowledge and forest plant species used by local populations of the Deng-Deng massif } \\
\text { forest against the Covid- } 19 \text { pandemic. Semi-structured questionnaires was used; and inquired } \\
\text { including the naturopaths, healers and heads of households (men and/or women). A total of } 405 \text { people } \\
\text { were interviewed in } 22 \text { villages. Available lexicons were used to find correspondence to the } \\
\text { vernacular/common names provided by inquired people. Five major Covid-19 symptoms including } \\
\text { fever, headache, cough, dyspnea, cold/nasal discharge were identified by local people and } 48 \text { forest } \\
\text { plants species were identified to prevent these symptoms, while } 26 \text { plant species were identified as } \\
\text { treatment of specific Covid-19 symptoms. The frequent use of the various plant species for the } \\
\text { prevention of the Covid-19 emerged as follow: Alstonia booneii (95\%), Annickia chlorantha ( } 72 \% \text { ), } \\
\text { Picralima nitida (50\%), Pycnanthus ivorensis (20\%) and Milicia excelsa (16\%). This study confirms } \\
\text { the importance of forest plant species in traditional medicine against the Covid-19 pandemic. }\end{array}$ \\
\hline
\end{tabular}

- Received: 03 May 2021 • Revised: 11 June 2021 • Accepted: 21 June 2021 • Published Online: 06 July 2021

\section{Introduction}

The contribution of plants in traditional medicine is well-established worldwide (Muhammad, 2020) and has been recognized by the WHO (Singh et al., 2010) as
$80 \%$ of the worldwide population relies on plant natural products for health. Compared to conventional drugs, plants are more accessible locally, cheap with little side effects (Tsabang et al., 2016). Most African local communities still relies on traditional medicine although 
it usually appears as the result of absence of modern health centers (Kognou et al., 2020; Vroh, 2020). Traditional medicine is commonly used to cure various diseases symptoms including fever, headache, cough, diarrhea, and nasal discharge (Ngwewondo et al., 2020), common symptoms of Covid-19.

Covid-19 is an emerging respiratory disease caused by the highly contagious SARS-CoV-2 virus. Firstly detected in December 2019 in China (Wuhan), it has so far been reported in more than 215 countries (Ngwewondo et al., 2020) and constitutes a major public health emergency concern (declared by the WHO $4^{\text {th }}$ March 2020). In Cameroon, the first confirmed case was observed on $6^{\text {th }}$ March 2020 and at the current date, the number of confirmed cases is 74946 with 1152 deaths. The virus is commonly spread when people come in close contact with each other. It is spread via small droplets produced when coughing, sneezing, and talking. One can get infected by touching a contaminated area and then touching their nose, eyes, and mouth. It is also possible for the virus to spread without showing any symptoms. The cold, cough, fever, tiredness and difficulty in breathing are the most common symptoms of Covid-19 (Vroh, 2020; Mondal et al., 2020; Fongnzossie et al., 2021); and people with lungs problems, cancer patients, chronic diseases, heart problem, high blood pressure, diabetic are more vulnerable (Ngwewondo et al., 2020). To limit and avoid the rapid spread of the ongoing Covid-19 outbreak in the countries several, Governmental measures were put in place.

As most viral diseases, two main approaches are recommended against the Covid-19. They include prevention and curative measures. There's currently no conventional and approved Covid-19 treatment. Various vaccines have been approved as emergency measures. This includes Astrazeneca, Fizer (Biontec), and many others from Russia and China. None of these vaccines guarantee an absolute protection against the currently known emerging strains of SARS-CoV-2 virus (e.g. Indian, South-African, English). Alongside the conventional medicine, the use of various plants extracts such as Artemisia has been recommended as treatment of various Covid-19 symptoms (Lui et al., 2009) and Covid-Organics (CVO+) capsules produced from the traditional plants in Madagascar, while many others were recommended as preventive method (Gourch et al., 2020; Vroh, 2020; Mondal et al., 2020, Muhammad, 2020; Fongnzossie et al., 2021).
The East region of Cameroon is the largest ecological zone in terms of surface area covered by forest, which nearly cover $80 \%$ of the regional land. Traditional medicine is of great importance to these living populations. Local populations currently believe that the low number of reported Covid-19 cases in the region is due to the regular consumption of plant decoctions (traditional medicine). Globally, this belief gained support from the WHO, which has welcomed traditional medicine in it strategy against the Covid-19 pandemic (Muhammad, 2020). It's therefore important to expand knowledge on the diversity of plants used in Covid-19 prevention or treatment in the East region of Cameroon, more precisely in the Deng-Deng massif.

\section{Materials and methods}

\section{Study site}

This study was carried out from January to March 2021 in 22 villages around the Deng-Deng forest massif. The relief of this area is relatively flat, with small low hills. The average altitude is 600 to $800 \mathrm{~m}$. The hydrographic network is dense and characterized by the presence of several tributaries. The climate is equatorial Guinean type, with four unevenly distributed seasons with count: two dry seasons (a short dry season from July to August and a long dry season from mid-October to mid-March) and two rainy seasons (a long rainy season from midMarch to June and a short rainy season from September to mid-October). The average annual temperature varies between $23{ }^{\circ} \mathrm{C}$ and $25{ }^{\circ} \mathrm{C}$; and the average rainfall of $1600 \mathrm{~mm} / \mathrm{year}$. The soils are essentially lateritic. Phytogeographically, the Deng-Deng massif belongs to the Guinean-Congolese domain (Letouzey, 1985) characterized by semi-deciduous with dominance of Cannabaceae and Malvaceae. The most common commercial species are Triplochiton scleroxylon, Pterocarpus sayauxii, Terminalia superba, Mansonia altissima, Entandophrama cylindricum, etc. In addition to wild logging, shifting cultivation, poaching and the collection of non-timber forest products (NTFPs) are the common activities that significantly contribute to the degradation of Deng-Deng massif forest.

\section{Data collection}

The methodological approach was based on the administration of a questionnaire that had been tested in advance, amended and updated. In each sampled village, a guide/translator has been used as a facilitator during the 
interviews with the resource persons. This facilitator was put at our disposition by the chiefs of each target village. The resource persons targeted for this study were mainly naturopaths, healers, and heads of households (men and/or women) who use traditional medicine for their household, relatives and non-family members. The interview with heads of household was done in presence of their spouse when it was possible in the perspective to obtain more information. Thus, a total of 405 questionnaires were administered in 22 randomly villages (Table 1). These villages belong to 5 main ethnic groups/clans, namely Bobilis, Kepere Deng-Deng, Mbamvele, Maka and Pols.
The questions were focused on general knowledge about the CoviD-19 pandemic, traditional preventive and curative measures against this pandemic, forest species and parts of these species used in these preventive and curative means against CoviD-19. Whenever this was possible, the local residents were bringing us to the trees near their houses, so that we could gather the information needed to identify them. However, it should be noted that with vernacular or commons names, identification was done using available lexicons (e.g. TIAMA (software program put in place by the Ministry in Charge of Forests); Onana and Mezili, 2018).

Table 1. Number of person inquired in respect to the village.

\begin{tabular}{lll}
\hline Cantons & Villages sampled & No. of inquired persons \\
\hline Bobilis & Ebaka & 5 \\
& Yebi & 21 \\
& Mbiombi & 18 \\
& Yanda & 25 \\
& Adiah & 12 \\
Kepere Deng-Deng & Ndemba 1 & 21 \\
& Mbaki 1 & 8 \\
& Mbaki 2 & 23 \\
Mbamvele & Bambo & 16 \\
& Satando & 17 \\
& Bizeh & 10 \\
Maka & Bikelka & 6 \\
& Bigomo & 9 \\
& Motombo & 24 \\
& Djaglassi & 38 \\
Pol & Bonando & 27 \\
& Petit Bonando & 7 \\
& Djamonomine & 12 \\
& Yoko-Betougou & 34 \\
\hline Total & Mbethen 1 & 29 \\
\hline
\end{tabular}

\section{Data analysis}

The survey forms were processed and encoded in an Excel spreadsheet. The analysis of the data was essentially based on descriptive analyses. The frequency of citation $(\mathrm{Fc})$ of species was calculated in order to evaluate the most commonly used species. It represents the percentage of informants citing the species $(\mathrm{S})$ in relation to the total number of informants surveyed $(\mathrm{N})$ $\mathrm{FC}=\mathrm{S} / \mathrm{N}$ X 100 (Dibong et al., 2020). The frequency of citation indicates the potential importance of the species reported in this study area. Knowledge of the citation frequency of a specific plant was used to determine its reliability and effectiveness in treatment of or more diseases.

\section{Results}

\section{Demographic characteristic of respondents}

The majority of local people inquired were male (71\%); and most of these inquired are belonging to the age class [30-40] year. Only 1\% has a higher education level; $20 \%$ have none level and 59\% with primary 
level. $80 \%$ of them are married and belong to the 5 mean ethnic groups. They were more Catholic (63\%) and their main occupation activity was Agriculture (86\%) (Table 2).

Table 2. Summary of demographic characteristic of respondents.

\begin{tabular}{|c|c|c|}
\hline \multicolumn{2}{|c|}{ Socio-demographic characteristic } & \multirow{2}{*}{$\begin{array}{l}\text { Percentage of respondents }(\%) \\
71\end{array}$} \\
\hline Gender & Male & \\
\hline & Female & 29 \\
\hline \multirow[t]{6}{*}{ Age (year class) } & $<20$ & 2 \\
\hline & [20-30] & 16 \\
\hline & {$[30-40]$} & 38 \\
\hline & [40-50] & 25 \\
\hline & {$[50-60]$} & 8 \\
\hline & $\geq 60$ & 12 \\
\hline \multirow[t]{4}{*}{ School level } & None & 20 \\
\hline & Primary & 59 \\
\hline & Secondary & 20 \\
\hline & Superior & 1 \\
\hline \multirow[t]{4}{*}{ Matrimonial statute } & Bachelor & 14 \\
\hline & Married & 80 \\
\hline & Divorced & 2 \\
\hline & Widower & 3 \\
\hline \multirow[t]{6}{*}{ Ethnical group } & Bobilis & 19 \\
\hline & Kepere Deng-Deng & 14 \\
\hline & Maka & 35 \\
\hline & Mbamvele & 12 \\
\hline & Pol & 15 \\
\hline & Others & 5 \\
\hline \multirow[t]{5}{*}{ Religion } & Adventist & 23 \\
\hline & Catholic & 63 \\
\hline & Moslem & 1 \\
\hline & Pentecotist & 8 \\
\hline & Protestant & 5 \\
\hline \multirow[t]{6}{*}{ Principal activity } & Agriculture & 86 \\
\hline & Craftsmen & 2 \\
\hline & Hunting & 3 \\
\hline & Naturopaths /healers & 5 \\
\hline & Civil servant & 2 \\
\hline & Others & 2 \\
\hline
\end{tabular}

According to the data survey, 94\% of local people inquired personally used traditional medicine for themselves and those of their family and others. 94\% of those who used traditional medicine have acquired it through heritage from their parents; only $6 \%$ percent acquired the knowledge by training from naturopaths or healers of the village. $65 \%$ of local people inquired collected medicinal plant used against Covid-19 symptom in forest; $17 \%$ and $18 \%$ say that their collected these plants in forest-agroforest-farm and forest-field-behind the house respectively.

\section{Knowledge of Covid-19 pandemic by local people of Deng-Deng forest massif}

Although no case of Covid-19 had been recorded in the Deng-Deng forest massif, all the local residents' surveyed said they had already heard about Covid-19 through various means like television/radio (69\%), conversation $(26 \%)$, sensibilization $(4 \%)$ and social media (1\%). However, when we asked them if they know about Covid-19 manifestations/symptoms in an affected person, 30\% said they do not know, as opposed 
to $70 \%$ who said they have only followed up through various means. The Covid-19 symptoms like identified by local people inquired are grouped in 5 main symptoms: Fever, Headache, Cough, Dyspnea, and Cold and nasal discharge.

\section{Preventive measures against Covid-19}

Only $87 \%$ of local people inquired applied preventive method against Covid-19. Measures prescribed by the Head of State are only applied when they leave their villages or go to town. However, at the village level, the preventive measures were essentially the use of medicinal plant decoctions ( $80 \%) ; 10 \%$ thought that taking their traditional wine 'kembé' or, 'ha'a', protects them against Covid-19. Only 10\% thought that it was the preventive methods like washing of hands with water and soap, using hydro-alcoholic gel, wearing face mask, and social distanciation which can protect them against Covid-19.

\section{Diversity of plant species used by local people like preventive or curative against Covid-19's symptoms}

A total of 48 forest plants species were identified for treatment or preventive measure against the Covid-19 symptoms. Among these plants, scientific name of 41 were identified and 7 were identified only with their vernacular names; these plant belong to 22 plant families (Table 3).

Table 3. List of Plant species identified in the treatment of Covid-19 symptom. Bo: Bobilis; Ma: Maka, Mb: Mbamvele, Po: Pol and Ke: Képré Deng-Deng. For symptom treated; $\mathrm{Fe}=\mathrm{fever} ; \mathrm{He}=$ headache; $\mathrm{Co}=\mathrm{Cough} ; \mathrm{Dy}=\mathrm{Dypnea}, \mathrm{Cl}=\mathrm{Cold}$ and nasal discharge.

\begin{tabular}{|c|c|c|c|c|c|c|}
\hline Common names & $\begin{array}{l}\text { Vernacular } \\
\text { names }\end{array}$ & Scientific names & Families & $\begin{array}{l}\text { Used by } \\
\text { ethnics }\end{array}$ & Parts used & $\begin{array}{l}\text { Treated } \\
\text { symptom }\end{array}$ \\
\hline Nsangomo & & Allablankia floribunda Oliv. & Clusiaceae & Bo, $\mathrm{Ma}$ & bark & $\mathrm{Co}, \mathrm{Cl}$ \\
\hline Emien & $\begin{array}{l}\text { Ikouk, rombo, } \\
\text { guga }\end{array}$ & Alstonia booneii De Wild. & Apocynaceae & $\begin{array}{l}\text { Bo, Ma, } \\
\text { Mb, Po, Ke }\end{array}$ & bark & $\mathrm{Fe}, \mathrm{He}$ \\
\hline Moambe jaune & Pol/poro & $\begin{array}{l}\text { Annickia chlorantha (Oliv.) } \\
\text { Setten \& Maas }\end{array}$ & Annonaceae & $\begin{array}{l}\text { Bo, Ma, } \\
\text { Mb, Po, Ke }\end{array}$ & bark & $\mathrm{Fe}, \mathrm{He}$ \\
\hline Moambe blanc & ébom & $\begin{array}{l}\text { Annonidium manii (Oliv.) } \\
\text { Engl. \& Diels }\end{array}$ & Annonaceae & Ma & bark & $\mathrm{He}$ \\
\hline Neem & & Azadirachta indica & Meliaceae & $\mathrm{Mb}$ & Bark & $\mathrm{He}, \mathrm{Fe}$ \\
\hline Moabi & Aya’a & Baillonnella toxisperma Pierrre & Sapotaceae & $\mathrm{Ke}, \mathrm{Ma}$ & bark & $\mathrm{Fe}, \mathrm{Dy}$ \\
\hline Ant tree & $\begin{array}{l}\text { Gokomo, } \\
\text { angokomo }\end{array}$ & Barteria fustulosa Mast. & Passifloraceae & $\mathrm{Ke}$ & bark & $\mathrm{He}, \mathrm{Fe}$ \\
\hline Kanda & noumkon & $\begin{array}{l}\text { Beilschmiedia obscura Engl. } \\
\text { ex Stapf }\end{array}$ & Lauraceae & $\mathrm{Ke}$ & Bark, fruit & Dy \\
\hline Ayélé & Bélé/ibigue & Canarium schweinfurthii Engl. & Burseraceae & $\mathrm{Bo}, \mathrm{Ke}, \mathrm{Ma}$ & bark & Dy \\
\hline Acacia & Acacia & Cassia spp. & $\begin{array}{l}\text { Leguminosae- } \\
\text { Caesalpinioideae }\end{array}$ & $\mathrm{Ke}$ & bark & $\mathrm{He}$ \\
\hline Squirrels' cola & bassindi & Cola sp. & Malvaceae & $\mathrm{Ke}$ & Bark & Dy \\
\hline Cordia & & Cordia platythyrsa Baker & Ehretiaceae & Ma & bark & $\begin{array}{l}\mathrm{Fe}, \mathrm{He}, \mathrm{Co} \text {, } \\
\mathrm{Cl}, \mathrm{Dy}\end{array}$ \\
\hline Okang & & $\begin{array}{l}\text { Cylicodiscus gabunensis } \\
\text { Harms }\end{array}$ & $\begin{array}{l}\text { Leguminosae- } \\
\text { Mimosoideae }\end{array}$ & Ma & $\begin{array}{l}\text { Leave, } \\
\text { Bark }\end{array}$ & $\begin{array}{l}\mathrm{Fe}, \mathrm{He}, \mathrm{Co}, \\
\mathrm{Cl}, \mathrm{Dy}\end{array}$ \\
\hline Bois d'ébene & & Disopyros crassiflora Hierm & Ebenaceae & Ma & bark & $\mathrm{He}$ \\
\hline Sapelli & Sei & $\begin{array}{l}\text { Entandrophragma cylindricum } \\
\text { Sprague (Sprague) }\end{array}$ & Meliaceae & $\mathrm{Ke}, \mathrm{Ma}$ & bark & $\mathrm{He}$ \\
\hline Tali & Londe, ngoulou & $\begin{array}{l}\text { Erythrpheum ivorensis } \\
\text { A.Chev. }\end{array}$ & $\begin{array}{l}\text { Leguminosae- } \\
\text { Caesalpinioideae }\end{array}$ & $\mathrm{Ke}, \mathrm{Ma}$ & bark & $\mathrm{He}, \mathrm{Co}$ \\
\hline \multirow[t]{2}{*}{ Eucalyptus } & & Eucalyptus sp. & Myrtaceae & $\mathrm{Mb}$ & Bark & $\mathrm{He}$ \\
\hline & wan & Ficus exasperate Vahl & Moraceae & $\mathrm{Ma}$ & bark & Dy \\
\hline Bitter kola & Yieul, wélé & Garcinia kola Heckel & Clusiaceae & $\mathrm{Bo}, \mathrm{Ke}, \mathrm{Ma}$ & Bark, seed & $\mathrm{Co}, \mathrm{Fe}, \mathrm{He}$ \\
\hline \multirow[t]{2}{*}{ Bubinga } & $\begin{array}{l}\text { Mbaya/tonde, } \\
\text { boka }\end{array}$ & Guirbourtia demeusei $\mathrm{L}$. & $\begin{array}{l}\text { Leguminosae- } \\
\text { Caesalpinioideae }\end{array}$ & Ma & bark & $\mathrm{He}$ \\
\hline & panpandé & Hylodendron gabunensis Taub. & $\begin{array}{l}\text { Leguminosae- } \\
\text { Caesalpinioideae }\end{array}$ & Ma & bark & $\mathrm{He}$ \\
\hline Mangue sauvage & Doko, Mbiya & $\begin{array}{l}\text { Irvingia goboneensis Baill. ex. } \\
\text { Lanen }\end{array}$ & Irvingiaceae & Ma & bark & $\mathrm{Fe}$ \\
\hline
\end{tabular}




\begin{tabular}{|c|c|c|c|c|c|c|}
\hline Common names & $\begin{array}{l}\text { Vernacular } \\
\text { names }\end{array}$ & Scientific names & Families & $\begin{array}{l}\text { Used by } \\
\text { ethnics }\end{array}$ & Parts used & $\begin{array}{l}\text { Treated } \\
\text { symptom }\end{array}$ \\
\hline golong & Ngolo & Khaya ivorensis A. chev. & Meliaceae & Bo, $\mathrm{Ma}$ & bark & $\mathrm{Fe}$ \\
\hline Iroko & Abang & $\begin{array}{l}\text { Milicia excelsa (Welw.) C.C. } \\
\text { Berg }\end{array}$ & Moraceae & Bo, Po, Ma & Sap, bark & $\mathrm{Fe}, \mathrm{He}, \mathrm{Co}$ \\
\hline parassolier & & $\begin{array}{l}\text { Mussanga cecropioides } \mathrm{R} \text {. Br. } \\
\text { apud Tedlie }\end{array}$ & Urticaceae & $\mathrm{Ke}, \mathrm{Ma}, \mathrm{Po}$ & bark & Co \\
\hline Monkey pineapple & $\begin{array}{l}\text { Dogo, ngata, } \\
\text { Idouk }\end{array}$ & Myrianthus arboreus Beauv. & Urticaceae & $\mathrm{Ke}, \mathrm{Pol}, \mathrm{Ma}$ & bark & $\mathrm{He}, \mathrm{Cl}$ \\
\hline \multirow[t]{2}{*}{ Bilinga } & Monsé, iza & $\begin{array}{l}\text { Nauclea diderrichii (De Wild. } \\
\& \text { T.Durand) Merrill }\end{array}$ & Rubiaceae & Bo, Ma, Mb & bark & Co, Dy \\
\hline & Adingding & Nauclea poboguenii & Rubiaceae & $\mathrm{Mb}$ & Bark & $\mathrm{Fe}, \mathrm{Dy}$ \\
\hline Kinkeleba & $\begin{array}{l}\text { Ibam, mbola, } \\
\text { gombeu }\end{array}$ & $\begin{array}{l}\text { Picralima nitida (Stapf) Th. \& } \\
\text { H. Durand }\end{array}$ & Moraceae & $\begin{array}{l}\text { Bo, Ma, } \\
\text { Mb, Po, Ke }\end{array}$ & Fruit, bark & $\mathrm{Fe}, \mathrm{He}, \mathrm{Dy}$ \\
\hline Dabema & & $\begin{array}{l}\text { Piptadeniastrum africanum } \\
\text { (Hook.f.)Brenan }\end{array}$ & $\begin{array}{l}\text { Leguminosae- } \\
\text { Mimosoideae }\end{array}$ & Ma & bark & $\mathrm{He}$ \\
\hline Cérisier rouge & Imbouri & Prunus cerasus & & $\mathrm{Mb}$ & Bark & $\mathrm{Co}$ \\
\hline \multirow[t]{2}{*}{ Ilumba } & Tingue, etin & $\begin{array}{l}\text { Pycnanthus ivorensis (Welw.) } \\
\text { Exell }\end{array}$ & Myristicaceae & $\begin{array}{l}\text { Bo, Ma, } \\
\text { Mb, Po, Ke }\end{array}$ & bark & Co \\
\hline & Ngomdé & Rauvolphia vomitoria Afzel. & Apocynaceae & $\mathrm{Bo}, \mathrm{Ke}$ & leaf & $\mathrm{Fe}$ \\
\hline \multirow[t]{2}{*}{ Djansang } & Izol & $\begin{array}{l}\text { Ricinninodedron heudolotii } \\
\text { (Baill.) Heckel }\end{array}$ & Euphorbiaceae & $\mathrm{Ke}, \mathrm{Bo}$ & bark & Co, Dy \\
\hline & Titemote & $\begin{array}{l}\text { Schumanniophyton magnificum } \\
\text { (K. Schum.) Harms }\end{array}$ & Rubiaceae & $\mathrm{Mb}$ & Bark & $\mathrm{He}, \mathrm{Fe}$ \\
\hline Tulipier of Gabon & Issoussou & Spathodea campanulata & Bignognaceae & Bo & Bark & $\mathrm{Co}, \mathrm{Cl}$ \\
\hline Fraké & Landeu, Ngolu & $\begin{array}{l}\text { Terminalia superba Engl. \& } \\
\text { Diels }\end{array}$ & Combretaceae & Ma & bark & $\mathrm{He}, \mathrm{Fe}$ \\
\hline Cacao & Kaka & Theobroma cacao L. & Malvaceae & $\mathrm{Ke}, \mathrm{Ma}$ & Bark, leaf & Co \\
\hline \multirow[t]{2}{*}{ Amvout } & $\begin{array}{l}\text { Mbouti, Ngoyo, } \\
\text { landar }\end{array}$ & Tricoschypha acumulata. Engl. & Anacardiaceae & $\begin{array}{l}\text { Bo, Ke, Ma, } \\
\text { Po, Mb }\end{array}$ & Bark, fruit & $\mathrm{Co}, \mathrm{Cl}$ \\
\hline & Hassan, assam & Uapaca spp. & Cannabaceae & $\mathrm{Bo}, \mathrm{Ke}, \mathrm{Ma}$ & & Co \\
\hline \multirow[t]{2}{*}{ Voacanga } & Itongli & $\begin{array}{l}\text { Voacanga africana Stapf ex } \\
\text { Scott-Elliot }\end{array}$ & Apocynaceae & $\begin{array}{l}\text { Bo, Ma, } \\
\text { Mb, Po, Ke }\end{array}$ & $\begin{array}{l}\text { Bark, leaf, } \\
\text { fruit }\end{array}$ & $\mathrm{He}, \mathrm{Fe}, \mathrm{Dy}$ \\
\hline & Binzou & Not identified & & Ma & Bark & $\mathrm{Fe}, \mathrm{He}, \mathrm{Co}$ \\
\hline \multirow[t]{6}{*}{ High Nivaquine } & $\begin{array}{l}\text { Kolcoîssi, } \\
\text { samanier }\end{array}$ & Not identified & & Bo, Ma & $\begin{array}{l}\text { Stem } \\
\text { (liana) }\end{array}$ & $\mathrm{Fe}$ \\
\hline & Nkoube & Not identified & & Ma & bark & Co, Dy \\
\hline & $\begin{array}{l}\text { Papadeh/ } \\
\text { papondé }\end{array}$ & Not identified & & Bo & Bark & $\mathrm{He}$ \\
\hline & Sambek & Not identified & & Ma & Bark & $\mathrm{Fe}$ \\
\hline & Foaleu & Not identified & & Ma & Bark & $\mathrm{He}, \mathrm{Fe}$ \\
\hline & Fande & Not identified & & Ma & bark & $\mathrm{Cl}$ \\
\hline
\end{tabular}

Among these medicinal plants identified, 6 of them were commonly used in all these five ethnic group studies. It is the case of: Alstonia booneii, Annickia chlorantha, Picralima nitida, Pycnanthus ivorensis, Tricoschypha acumulata, Voacanga africana. Some of them were specifically used only by one, two, three or four studied ethnic groups. For example the case of Azadirachta indica, Eucalyptus sp., Nauclea poboguenii, Prunus cerasus which have been identified only for Mbamvele clan group; and Barteria fistulosa, Beilschmiedia obscura, Cassia spp. and Cola sp. Which have been identified only for Kepere Deng-Deng clan group (Table 3).
Different parts of medicinal plants used by local people for the treatment or prevention of some diseases are: barks, fruits, leaves, seeds, sap and stems (liana). For some plant species, they used barks and fruits, barks and leaves. In general; the barks of $80 \%$ of plant species identified are used by the local populations in the preparation of medicinal plant decoction used for the treatment against Covid-19, 7\% of these plants, their barks associated to the fruits of others plants to treat the Covid-19 and $4 \%$ of barks of these plants are associated with the leaves of some plants.. Concerning leaves, bark-seed, bark-sap, bark-leaves-fruit and stem (liana), they represented $2 \%$ each. 
Concerning plants used in the treatment of Covid-19 symptoms, 26 plant species have been identified as treating a specific symptom among the 5 symptoms of Covid-19 identified. Then, 5 (10\% of total medicinal plants identified) are used by local peoples against cough (Co) treatment; 4 (8\%) medicinal plant species are used against Dyspnea (Dy), 5 (10\%) medicinal plant species are used against Fever (Fe), and $10(21 \%)$ against Headache $(\mathrm{He})$. among these plant species, $2 \%$ are used for the treatment of treat all the Covid-19 symptoms, 3 plant species $(6 \%)$ are used against CoughDypnea, 3 (6\%) against Cough-Cold/nasal discharge and Fever-Dypnea each; 1 plant species $(2 \%)$ against Headache-col/nasal discharge and Headache-Cough. Concerning the number of plant species used in the treatment of 3 Covid-19 symptoms, 3 and 2 plant species are used to treat respectively Fever-HeadacheCough and Fever-Headache-Dypnea. Only two medicinal plant species $(4 \%)$ have been identified like treating all the 5 Covid-19 symptoms; these 2 plant species were Cordia platythyrsa and Cylicodiscus gabunensis; they were identified only in Maka ethnic group (Table 3).

\section{Plant species most implicated against Covid-19's symptoms preventive or curative}

According to citation frequency of plant species used against Covid-19 symptom, most plant species whose citation frequency are at least $10 \%$ are present in the Fig. 1. Thus, 12 plant species count between the 45 plant species identified were: Alstonia booneii (95\%), Annickia chlorantha (72\%), Picralima nitida (50\%), Pycnanthus ivorensis (20\%), Milicia excelsa (16\%), Tricoschypha acumulata (15\%), Voacanga africana (15\%), Mussanga cecropioides (14\%), Myrianthus arboreus (12\%), Garcinia kola (11\%), Rauvolfia vomitoria (10\%) and Allablankia floribunda (10\%).

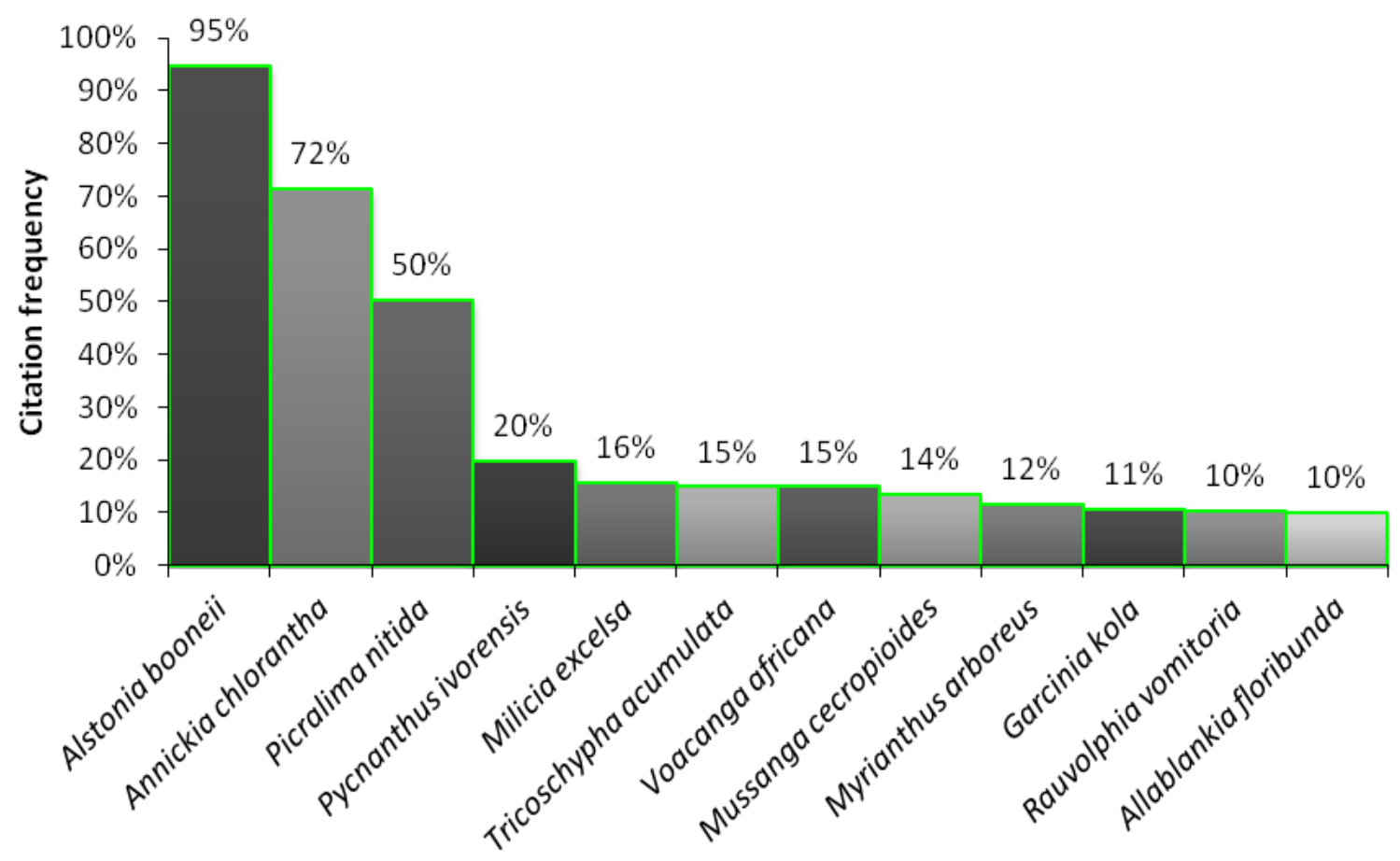

Fig. 1: Main species used by local people against Covid-19 symptoms.

\section{Discussion}

In Cameroon like in many other sub-Saharan African countries, the advent of modern medicine has not reduced the confidence placed in traditional medicine by rural populations, who commonly use plants for the treatment of several diseases (Fongnzossie et al., 2021). It is in this light that endogenous knowledge of traditional medicinal plants have a very high importance for the improvement of the health status of local populations. Indeed, as it was the case in this study, traditional medicine occupies a place of choice in the 
habits of the local populations of the Deng-Deng forest massif because almost all the persons surveyed use medicinal plants for themselves, their families and others persons. This is justified by the diversity of 45 species of medicinal forest plants identified in the Deng-Deng forest massif as part of the preventive and curative measures related to the symptoms of Covid-19. As it was also observed in this study, several authors had already shown the importance of traditional medicine as a mean of prevention/treatment of Covid-19 symptoms (Mpondo et al., 2017; Gourch et al., 2020; Vroh, 2020; Mondal et al., 2020; Muhammad, 2020; Fongnzossize et al., 2021).

With respect to the Covid-19 related symptoms as perceived by Deng-Deng residents, socio-economic surveys carried out among 424 residents revealed 5 major Covid-19 related symptoms (headache, fever, cough, cold/nose discharge and breathing difficulties) which are similar to those found by several authors in sub-Saharan Africa (Gourch et al., 2020; Vroh, 2020; Fongnzossie et al., 2021). It is the specific richness of 45 forest species that are used to alleviate these Covid19 symptoms; among these species four (4) (Cola spp., Khaya sp., Rauwolfa sp, Terminalia sp.) have already been confirmed as containing secondary metabolites as anti-Covid-19 molecules (Fongnzossize et al., 2021). With the literature review in Cameroon conducted by Fongnzossize et al. (2021) on plant species alleviating Covid-19 related symptoms, eleven species common to these authors have been also listed in this study to treat the same symptoms. These are: Alstonia booneii, Annickia chloranta, Azadirachta indica, Cola spp, Diospyros sp, Eucalyptus sp., Garcinia kola, Khaya sp, Milicia excelsa, Picralima nitida, Spathodea campanulata, Terminalia sp. However, the richness of 45 species found in this study is low compared to the 99 of 230 species recorded by Vroh (2020) and Fongnzossie et al. (2021) this difference could be explained by the fact that these authors have done a literature review of species potentially used against Covid-19 in Sub-Saharan Africa and Cameroon, whereas we only surveyed the ethnic groups around the Deng-Deng forest massif. Furthermore, we limited ourselves to woody forest species whereas these authors inventoried all plants including herbaceous, ruderal, fruit trees, etc. Globally, we can note that plant species which have a high citation frequency are those which are perceived by local population as more efficient against Covid-19 symptom. It is the case of the species identified with citation frequency greater than $10 \%$.
Despite the fact that leaves and fruits could be responsible for medicinal properties as they accumulate the most molecules such as antioxidants, vitamins, inulins, tannins and other alkaloids (Kpatcha et al., 2016), we found in this study that for $80 \%$ of the identified species, it is the bark that is used, which is contrary to the work of Fongnzossie et al. (2021). This can be explained by the fact that, since we limited ourselves only to woody forest species generally reaching up to $40 \mathrm{~m}$ in height, it is mostly the bark that is easily accessible; therefore, the choice relies on individuals with a large diameter as they have high quantities of molecules with medicinal properties.

It should be noted that the habits of the populations are also a factor influencing the choice of species used. This is the case, for example, of the barks of Allanblanckia floribunda and Polyscias fulva listed in the literature as treating coughs (Mpondo et al., 2017), whereas in the context of this study, it is Pycnanthus angolensis that is the species most used to relieve coughs. Fongnzossie et al. (2021) reviewed the literature on medicinal plants used against Covid-19 did not listed this species although it had a high frequency of citation in the study area.

\section{Conclusions}

The present study allows an inventory to be made of the forest plants potentially effective against the major symptoms of Covid-19 (headache, cough, fever, breathing difficulties and runny nose/cold) identified by the residents of the Deng-Deng forest massif. A total of 48 plants forest species have been identified as commonly used by local people living in the area to prevent or treat Covid-19 symptoms. Species with a citation frequency of more than $10 \%$ were: Alstonia booneii (95\%), Annickia chlorantha (72\%), Picralima nitida (50\%), Pycnanthus ivorensis (20\%), Milicia excelsa (16\%), Tricoschypha acumulata (15\%), Voacanga africana (15\%), Mussanga cecropioides (14\%), Myrianthus arboreus (12\%), Garcinia kola (11\%), Rauvolphia vomitoria (10\%) and Allablankia floribunda (10\%). Thus, this study further confirms the attachment of the local populations to traditional medicine.

It should be noted that although this study is a significant contribution to the knowledge of plant species used in the prevention or treatment of Covid-19, it does not justify the use of these species in any form 
for the prevention or treatment of this pandemic unless clinically tested and approved. However, although the active ingredients and efficacy of some of these species have already been proven, we believe that the results of this study could contribute to a greater focus on the biochemical properties of those for which the information is still unknown in order to assess the clinical value of the main compounds derived from these plants against the symptoms of Covid-19 and therefore their large scale valorization.

\section{Conflict of interest statement}

Authors declare that they have no conflict of interest.

\section{Acknowledgement}

Our heartfelt gratitude to the Conservation Action Research Network (CARN 2020) which provided the financial assistance for the accomplishment of this study. We express our gratitude to Conservation and Sustainable Natural Resources Management Network (CSNRM-Net) who have provided us their expertise on the field during socio-economic survey. This study would not have been possible with-out the hospitality of respondents who were available to answer the questionnaires. We express also our gratitude to independent reviewers for their scientific inputs in to this manuscript.

\section{References}

Dibong, S.D., Etamé, G.L., Okalla, C.E., Ngaba, G.P., Guemkam, V. G., Yinyang, J., Nnanga, N.E., Mpondo, M.E. 2020. Contribution à l'étude ethnobotanique des plantes médicinales traitant les maladies de l'appareil digestif des peuples Bamouns au Cameroun. Ethnopharmacologia, 63: 58-69.

Fongnzossie, F.E., Biwole, A.B., Nyangono, B.C.F., Ngansop, T.M., Akono, P.N., Essono, D. M., Forbi, P.F., Tonga, C., Nguenang, G.M., Kemeuze, V., Sonwa, D.J., Tsabang, N., Isabelle S.B., Tize, Z., Boum, A.T., Momo, S.M.C., Betti, J.L., Nouga, B.A., Lehman, L.G., Mapongmetsem, P.M., Ngono, N.A., Ngogang, Y.J. 2021. A review of Cameroonian medicinal plants with potentials for the management of the COVID- 19 pandemic. Adv. Tradit. Med., https://doi.org/10.1007/s13596021-00567-6

Gourch, A., Zejli, H., Lfitat, A., Bousraf, Z.F., El Atki, Y., Ainane, A., Ainane, T., Abdellaoui, A., El-
Hajjaji, F., Rais, Z., Taleb, M. 2020. Preventive impact of traditional medicine against covid-19. J. Anal. Sci. Appl. Biotechnol., 2: 78-82.

Liu, N.Q., Van der Kooy, F., Verpoorte, R., 2009. Artemisia afra: A potential flagship for African medicinal plants? South Afr. J. Bot., 75: 185-195.

Kognou, M.L.A., Theodora, K.K., Pradeep, P.P., Prem, N.P., Mouokeu, S.R., Tiabou, T.A., Agbor, A.G., Singh, O.R., Ngane, N., 2020. Pharmacological evidence of Vitex thyrsiflora, Entandrophragma cylindricum, and Anonidium mannii used for the management of inflammation in Cameroon. J. Basic Clin. Physiol. Pharmacol., 31: 1-14.

Kpatcha, T., Agbonon, A, Gbeassor, M., 2016. Food plants used during traditional wrestling in Kabyè land of Togo. Pan Afr. Med. J., https://doi/10.11604/pamj.2016.23.25.7719

Letouzey, R., 1985. Notice de la carte phytogéographique du Cameroun au 1:500000 (Toulouse: Institut de la carte internationale de la végétation).

Liu, N.Q., Van der Kooy, F., Verpoorte, R., 2009. Artemisia afra: A potential flagship for African medicinal plants? South Afr. J. Bot., 75: 185-195.

Mondal, P., Natesh, J., Salam, A.A.A., Thiyagarajan, S., Meeran, M.S., 2020. Traditional medicinal plants against replication, maturation and transmission targets of SARS-CoV-2: computational investigation. J. Biomol. Struct. Dyn., https:// doi.org/10.1080/07391102.2020.1842246

Mpondo, M.E., Ngene, J.P., Som M.L., GE L., Boumsong, N.P.C., Yinyang, J., Dibong, S.D. 2017. Connaissances et usages traditionnels des plantes médicinales du département du haut Nyong. J. Appl. Biosci., 113: 11229-11245.

Muhammad, F., 2020. COVID-19 Pandemic: The role of traditional medicine. Int. J. Infect. (In Press): e107090. https://doi.org/10.5812/iji.107090.

Ngwewondo, A., Nkengazong, L., Ambe, L. A., Ebogo, J. T., Mba, F. M., Goni, H. O., Nyunaï, N. M., Ngonde, C., Oyono, E. J. L., 2020. Knowledge, attitudes, practices of/towards COVID19 preventive measures and symptoms: A cross-sectional study during the exponential rise of the outbreak in Cameroon. PLoS Negl. Trop. Dis., 14(9): e0008700.

Onana, J.M., Mezili, P., 2018. Recueil des noms des plantes en langues ethniques du Cameroun. Edition Université Européenne, 171p.

Singh, P., Shukla, R., Kumar, A., Prakash, B., Singh, S., Dubey, N.K., 2010. Effect of Citrus reticulata and 
Cymbopogon citratus essential oils on Aspergillus flavus growth and aflatoxin production on Asparagus racemosus. Mycopathologia, 170(3): 195-202.

Tsabang, N., Guedje, N.M., Fokunang, C., Dongmo S., Tchokouaha, Y.L.R., Fokou, T.P.V., Jiofack, R., Tarkang, P.A., Nouidui, C. Fekam, B.F., 2016. Ethnopharmacological and ethnomedical Study of anti epileptic plants used in traditional medicine in Yaounde and its surroundings areas (Cameroon). J. Biol. Chem. Res., 33(1): 496-509.

Vroh, B. T. A., 2020. Plant species used in traditional medicine against the main symptoms of COVID-19 in Sub-Saharan Africa: literature review. Ethnobot. Res. Appl., 20: 26, 1-14.

\section{How to cite this article:}

Inimbock, S.L., Chimi, D.C., Enamba, Y.C., Tsemo, T.D.C., Somnjom, E.D., Mounmenie, K.H., Bogne, T.L.V., Noudem, J.C., Nanfack, T.C.L., Misse, A.C., 2021. Contribution to traditional knowledge used for the prevention and healing of the Covid-19 symptoms by local people of Deng-Deng massif forest Cameroon. Int. J. Curr. Res. Biosci. Plant Biol., 8(7): 7-16. doi: https://doi.org/10.20546/ijcrbp.2021.807.002 